\title{
Incidence of paramalignant disorders in bronchogenic carcinoma
}

\author{
JOSEPH W. RASSAM and GERALD ANDERSON \\ St. Woolos Hospital, Newport, Gwent
}

\begin{abstract}
Rassam, J. W. and Anderson, G. (1975). Thorax, 30, 86-90. Incidence of paramalignant disorders in bronchogenic carcinoma. The incidence of paramalignant disorders was studied in 280 consecutive patients with early lung cancer confirmed histologically. The commonest disorders were weight loss exceeding $6.4 \mathrm{~kg}(30.7 \%$ of the series), finger clubbing $(29 \%)$, fever $(21 \cdot 1 \%)$, and endocrinopathies $(12 \cdot 1 \%)$. Paramalignant diseases are common even in early lung cancer and all patients should have investigations for their detection.
\end{abstract}

Paramalignant (syn. non-metastatic) disorders are those conditions associated with malignancy which cannot be attributed either to the mechanical effect of the tumour or to its metastases. Differing accounts of their frequency in lung cancer may reflect the stage of the disease in the group being studied because they are commoner in advanced cancer. This study is of a series of patients with lung cancer where the group as a whole were at an early stage of their disease.

\section{PATIENTS AND METHODS}

Studies were made on 280 consecutive patients with histologically confirmed bronchogenic carcinoma admitted to a chest unit over a period of four and one half years. The proportions of different cell types is shown in Table I. Ninety (32.5\%) of the patients were referred as a result of an abnormal mass miniature radiograph. All studies were made at the time of the patient's first admission to hospital. A separate prospective study of finger clubbing was made on 76 consecutive patients within the group.

When taking the patient's history and making the clinical examination particular attention was directed to the manifestations of paramalignant disorders. The following investigations were made on all patients:
Haemoglobin and blood indices, serum levels of ot calcium, inorganic phosphorus, alkaline phosphatase, urea, glucose, sodium, potassium and chloride. The urine was tested for glucose and protein.

In all patients with marked finger clubbing radio-o graphs were taken of the extremities to detect thoo presence of hypertrophic osteoarthropathy. Other in vestigations, such as estimations of serum thyroxine levels, were performed when indicated clinically or as a result of the initial investigations.

The following diagnostic criteria were observed:o finger clubbing was recorded only when three indepen dent observers agreed to its presence and hypertrophic osteoarthropathy when a patient with finger clubbing showed radiographic evidence of periostitis; significant weight loss, when it exceeded $6.4 \mathrm{~kg}$ (one stone) anaemia when the haemoglobin level was less than $10.0 \mathrm{~g} / 100 \mathrm{ml}$ (anaemia was considered normocytic when the mean corpuscular volume exceeded $75 \mu \mathrm{g}$ and microcytic when it did not); hypercalcaemia when the serum calcium exceeded $11.5 \mathrm{~g} / 100 \mathrm{ml}$ on two or more occasions; hyponatraemia due to inappropriate antidiuretic hormone (ADH) secretion when the serum sodium was less than $125 \mathrm{mEq} / 1$ and the urine was hyperosmolar to the plasma; fever with an oraN temperature in excess of $37.5^{\circ} \mathrm{C}$ on three or morw occasions during admission (excluding postoperative pyrexia); hyperthyroidism when the serum thyroxine

T A B L E I

HISTOLOGICAL TYPES OF BRONCHOGENIC CARCINOMA IN GROUP STUDIED

\begin{tabular}{|c|c|c|c|c|c|}
\hline No. of Patients & $\begin{array}{l}\text { Squamous } \\
\text { Carcinoma }\end{array}$ & $\begin{array}{c}\text { Oat-cell } \\
\text { Carcinoma }\end{array}$ & $\begin{array}{l}\text { Undifferentiated } \\
\text { Carcinoma }\end{array}$ & Adencarcinoma & $\begin{array}{l}\text { Cell Type } \\
\text { Unspecified }\end{array}$ \\
\hline 280 & $167.69 \%$ & $\begin{array}{l}42 \\
15.0 \%\end{array}$ & $32.4 \%$ & $25.9 \%$ & $145.0 \%$ \\
\hline
\end{tabular}


was more than $13.5 \mu \mathrm{g} / 100 \mathrm{ml}$; diabetes mellitus when a patient with glycosuria had a plasma glucose level above $120 \mathrm{mg} / 100 \mathrm{ml}$ two hours after $50 \mathrm{~g}$ of glucose by mouth. Diabetes was considered to be related to the cancer when it was diagnosed within three months of the lung tumour being discovered.

\section{RESULTS}

The incidence of paramalignant disorders in the group is summarized in Table II. The commonest abnormalities were significant weight loss, finger clubbing, fever, and endocrine and metabolic disorders. Some patients showed more than one paramalignant disorder; for example, weight loss exceeding one stone was present in 14 of 19 patients with non-metastatic hypercalcaemia, and one patient had both thyrotoxicosis and nonmetastatic hypercalcaemia.

SIGNIFICANT WEIGHT LOSS This was the commonest paramalignant disorder. All three patients with hyperthyroidism had significant weight loss. In the whole group only three patients had gained weight.

FINGER CLUBBING AND HYPERTROPHIC OSTEOARTHROPATHY Finger clubbing was present in 22 of 76 patients $(29 \%)$. It is difficult to make an objective assessment of the severity of finger clubbing but there was an impression that gross clubbing was associated with squamous tumours. Hypertrophic osteoarthropathy was detected in nine patients of the $280(3.9 \%)$, only two of whom had an arthropathy. Oedema occurred in three, and gynaecomastia and bone pain in one.

FEVER Fever was present in $59(21 \cdot 1 \%)$ patients. In 51 of these it seemed reasonable to attribute the pyrexia to a chest infection, either because the sputum was purulent or a bronchial block allowed distal infection. In two further patients a drill biopsy of the tumour showed it to be necrotic and fever was attributed to this, while two patients had urinary tract infections and one thrombophlebitis migrans. In only three patients was there no other apparent reason for the fever.

ENDOCRINE AND METABOLIC DISORDERS Endocrine and metabolic disorders were present in 34 $(12.1 \%)$ patients and the incidence of the different conditions is shown in Table III. Excluded from consideration were three patients with hypercalcaemia and bone metastases and five with previ-

T A B L E I I

INCIDENCE OF PARAMALIGNANT SYNDROME IN 280 PATIENTS WITH BRONCHOGENIC CARCINOMA AND RELATION TO HISTOLOGICAL TYPE OF TUMOUR

\begin{tabular}{|c|c|c|c|c|c|c|c|}
\hline \multirow[t]{2}{*}{ Type of Paramalignant Disorder } & \multirow[t]{2}{*}{ Number } & \multicolumn{5}{|c|}{ Histological Type ${ }^{1}$} & \multirow[t]{2}{*}{ Percentage } \\
\hline & & $\mathbf{s}$ & 0 & $\mathbf{u}$ & $\mathbf{a}$ & $?$ & \\
\hline $\begin{array}{l}\text { Weight loss > } 7.4 \mathrm{~kg} \\
\text { Finger clubbing } \\
\text { Fever } \\
\text { Endocrine or metabolic disorder } \\
\text { Anaemia } \\
\text { Hypertrophic osteoarthropathy } \\
\text { Clotting disorders } \\
\text { Gastrointestinal haemorrhage } \\
\text { Neuromyopathies } \\
\text { Skin disorders }\end{array}$ & $\begin{array}{c}86 \\
22 / 76 \\
59 \\
34 \\
22 \\
9 \\
10 \\
5 \\
4 \\
2\end{array}$ & $\begin{array}{r}56 \\
14 \\
38 \\
27 \\
14 \\
8 \\
5 \\
3 \\
1 \\
2\end{array}$ & $\begin{array}{r}9 \\
1 \\
10 \\
3 \\
2 \\
1 \\
1 \\
3 \\
-\end{array}$ & $\begin{array}{r}11 \\
1 \\
2 \\
2 \\
4 \\
= \\
= \\
=\end{array}$ & $\begin{array}{l}6 \\
3 \\
5 \\
2 \\
1 \\
2 \\
1 \\
-\end{array}$ & $\begin{array}{l}4 \\
3 \\
4 \\
2 \\
2 \\
-\end{array}$ & $\begin{array}{l}30 \cdot 7 \\
29 \cdot 0 \\
21 \cdot 1 \\
12 \cdot 1 \\
7 \cdot 9 \\
3 \cdot 2 \\
3 \cdot 6 \\
1 \cdot 8 \\
1 \cdot 4 \\
0 \cdot 7\end{array}$ \\
\hline
\end{tabular}

${ }^{1} \mathrm{~s}=$ squamous $; 0=0$ at cell $; \mathrm{u}=$ undifferentiated; $\mathbf{a}=$ adenocarcinoma $; ?=$ cell type uncertain.

T A B L E I I I

INCIDENCE OF ENDOCRINE AND METABOLIC DISORDERS IN 280 PATIENTS WITH BRONCHOGENIC CARCINOMA AND RELATION TO HISTOLOGICAL TYPE OF TUMOUR

\begin{tabular}{|c|c|c|c|c|}
\hline & Number & Histolo & gical Type & Percentage \\
\hline $\left.\begin{array}{l}\text { Hypercalcaemia } \\
\text { Inappropriate ADH secretion } \\
\text { Diabetes mellitus }{ }^{2} \\
\text { Gynaecomastia } \\
\text { Hyperthyroidism } \\
\text { Ectopic-ACTH syndrome } \\
\text { Carcinoid syndrome } \\
\text { Hypoglycaemia } \\
\text { Amyoidosis }\end{array}\right\}$ & $\begin{array}{r}19 \\
3 \\
5 \\
3 \\
3 \\
1 \\
0\end{array}$ & $\begin{array}{l}s=19 \\
o=2 \\
s=2 \\
s=3 \\
s=3 \\
o=1\end{array}$ & $\begin{array}{l}u=1 \\
u=1, \quad a=2\end{array}$ & $\begin{array}{l}6.8 \\
1.1 \\
1.8 \\
1.1 \\
1.1 \\
0.4 \\
0\end{array}$ \\
\hline
\end{tabular}

${ }^{1} s=$ squamous; $\quad 0=$ oat cell; $u=$ undifferentiated; $a=$ adencarcinoma; $\quad$ =cell type uncertain.

${ }^{2}$ Excluding (i) patients with long standing diabetes

(ii) a single patient with diabetes and the ectopic-ACTH syndrome. 
ously discovered diabetes mellitus. Non-metastatic hypercalcaemia was the commonest form of endocrinopathy, occurring in $19(6.8 \%$ of the group). All these patients had squamous carcinoma and none had clinical or radiological evidence of bony secondaries. In two patients the hypercalcaemia was relieved by resection of the tumour and in seven by radical radiotherapy to the chest.

Inappropriate antidiuretic hormone secretion was detected in three patients $(1.1 \%)$, two with an oat-cell and one with an anaplastic tumour. In only one patient did the hyponatraemia fail to respond to a restricted water intake. In the patient who received radiotherapy to the tumour the serum sodium returned to normal and remained so even with a normal fluid intake.

Newly diagnosed diabetes mellitus was present in five patients, four with an anaplastic and one with a squamous-cell tumour. The diabetes was controlled with carbohydrate restriction alone. A further patient had diabetes mellitus associated with the ectopic-ACTH syndrome.

Gynaecomastia was present in three patients $(1.1 \%)$; in one it was associated with hypertrophic osteoarthropathy. Hyperthyroidism was detected in three patients; goitre and eye signs were absent but tachycardia, weight loss, and dyspnoea were prominent features. In one patient following irradiation of the tumour the serum thyroxine returned to normal; the remaining two cases responded to carbimazole. One of the thyrotoxic patients also had hypercalcaemia. The ectopic -ACTH syndrome was seen in a single patient.

ANAEMIA Anaemia was present in $22(7.9 \%)$ patients; it was microcytic in 12 and normocytic in 10. Squamous tumours were present in 14 of the 22 anaemic patients. The anaemia was attributed to a haematemesis in two patients and to intrathoracic suppuration in a further two. Of the remaining 18 , in only three was haemoptysis considered severe enough to result in anaemia.

CLOTTING DISORDERS Venous thrombosis was detected clinically in eight patients $(2.9 \%)$ and none showed evidence of pulmonary embolization. A further patient had thrombophlebitis migrans and one showed splinter haemorrhages in the nail bed possibly due to emboli from non-bacterial thrombotic endocarditis.

GASTROINTESTINAL HAEMORRHAGE Two patients were admitted as a result of gastrointestinal haemorrhages and a routine chest radiograph revealed a bronchogenic carcinoma; three patients? sustained gastrointestinal haemorrhages during

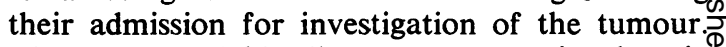
The sources of bleeding were a gastric ulcer in two, a duodenal ulcer and a hiatus hernia in one each, and the source was uncertain in the other $\overrightarrow{0}$

NEUROMYOPATHIES Neuromyopathies were un $\vec{\omega}$ common, being present in only four patients $(1.4 \%)$, three had mixed peripheral neuropathies and one of these also had a myelopathy. A single patient had cerebellar degeneration.

SKIN DISORDERS Skin disorders were present in only two patients $(0.7 \%)$; one had generalizedi pruritus and the other had generalized Bowen'sO disease (intraepidermal carcinoma of the skin) Some patients, especially those with advanced cancer, noted a generalized increase in skin pig $\overrightarrow{0}$ mentation; these were not included because it wast difficult to measure objectively.

\section{DISCUSSION}

As a group the patients were studied early on iñ the course of their disease because a high propor tion were referred from a mass miniature radio $\vec{\nabla}$ graph unit and they were studied at their firs $\bar{B}$ hospital admission. The results therefore show a likely minimum estimate of the frequency op paramalignant disorders which nevertheless are seen to be common.

Significant weight loss was the commonest para malignant disorder. A point of diagnostic impor $\frac{0}{3}$ tance is that weight gain makes the diagnosis. of bronchogenic carcinoma very unlikely. The theories seeking to explain the pathogenesis of weight loss in cancer have recently been reviewed (Anderson, 1973).

Finger clubbing was diagnosed on the indepen dent clinical impression of three observers. Objec요 tive measurements of the phalanx can be made्t from plaster casts but this method is too cumber some for clinical use and we found good agree $\omega$ ment between these experienced observers. The incidence of hypertrophic osteoarthropathy is similar to the $4 \%$ found in the series of Yacoub (1965). The fact that arthropathy is an inconstant ${ }^{+}$ feature of the disease has recently been stressed (Anderson, 1973). We confirmed the finding of Yacoub (1965) that none of the patients with hypertrophic osteoarthropathy had oat-celp tumours. 
Fever in lung cancer has been attributed to an unknown effect of the tumour. In support of this, Barrett (1967) described a patient with a pyrexia present for four years which resolved following resection of an anaplastic bronchogenic carcinoma $1 \mathrm{~cm}$ in diameter. The evidence from the present series is that such unexplained fever is rare.

Endocrine and metabolic diseases may produce striking clinical manifestations, but in this series more often they were undetected clinically and it should be mandatory to perform a series of simple biochemical tests (vide supra) to detect them. In lung cancer hypercalcaemia is more commonly a paramalignant disorder than a result of bony metastases. The incidence of hypercalcaemia of $6.8 \%$ in this series corresponds to the $8.5 \%$ found by Azzopardi, Freeman, and Poole (1970) and the $6 \%$ found by Carey (1966). In advanced lung cancer it is even commoner, being present in $32 \%$ of terminal patients (Azzopardi and Whittaker, 1969). Radiotherapy to or resection of the tumour rapidly relieves non-metastatic hypercalcaemia.

The incidence of the syndrome of inappropriate $\mathrm{ADH}$ secretion was $1.1 \%$ compared to $1.6 \%$ found by Azzopardi et al. (1970). In two of our three patients the disorder was asymptomatic while the remaining patient developed confusion and a fit due to water intoxication. Radiotherapy produced a rapid rise in serum sodium in one patient, and hyponatraemia did not recur when she developed massive liver metastases, suggesting that the secondary deposits lacked the ability to produce ADH. The incidence of diabetes of $1.8 \%$ was higher than the expected $0.8 \%$ of the general population (College of General Practitioners, 1962) and although the difference is not statistically significant we were impressed by the simultaneous onset of the symptoms of cancer and those of diabetes. A diabetic glucose tolerance test (GTT) was present in $41 \%$ of lung cancer patients in one series compared to $9 \%$ of a control group (Glicksman and Rawson, 1956). The raised serum cortisol level found in the majority of cancer patients (Hatch, Segaloff, and Ochsner, 1965) possibly causes peripheral antagonism to insulin, producing an abnormal GTT in some patients and precipitating frank diabetes in others.

Gynaecomastia was found in $1.1 \%$ and hypertrophic osteoarthropathy is known to be accompanied by gynaecomastia in about $8 \%$ of cases (Semple and McCluskie, 1955). Hyperthyroidism has been described in patients with lung cancer (de Gennes, Bricaire, and Leprat, 1962; Pisapia, 1965), and in a single clinically euthyroid patient the serum contained thyroid-stimulating hormone (TSH-like substance). The relief of thyrotoxicosis after radiotherapy to the tumour in our patient is compatible with ectopic production of a TSHlike substance or thyroxine itself. The ectopic -ACTH syndrome was present in only $0.4 \%$ of patients. This was a surprisingly low incidence since Rees (1973) has shown that most oat-cell tumours produce ACTH to a greater or less extent.

The incidence of neuromyopathies of $1.4 \%$ is in contrast to that of $16 \%$ found in lung cancer patients by Croft and Wilkinson (1963). These authors considered the commonest form of neuromyopathy to be a proximal myopathy but we found this disorder difficult to distinguish from cancer cachexia and classified these patients as showing significant weight loss. The patients studied by Croft and Wilkinson were possibly at a more advanced stage of their disease and their criteria for diagnosing a neuromyopathy were those of minimal neurological abnormality.

Anaemia in lung cancer may result from haemoptysis or from inadequate iron intake. Neither was considered an important factor in the anaemic patients in this study. Anaemias were about equally divided into microcytic and normocytic types, and cancer anaemia probably results from a combination of increased haemolysis and ineffective erythropoesis so that while marrow activity is increased the number of erythrocytes in the peripheral blood is not.

The incidence of venous thrombosis was only $2.9 \%$ but the majority of patients were in hospital for less than seven days and were mobilized as much as possible. In malignancy the level of activity of both clotting and bleeding mechanisms may be set at a higher level than normal (Soong and Miller, 1970) so that patients may develop either a clotting or a bleeding tendency. The patient with splinter haemorrhages possibly had non-bacterial thrombotic endocarditis which is associated with a variety of terminal illnesses and is found in about $1 \%$ of all necropsies (Eliakim and Pinchas, 1966).

Skin disorders were rare; pruritus is not a specific disorder in lung cancer. In one series of 35 patients with Bowen's disease, $28(80 \%)$ subsequently developed one or more visceral malignancies or a metastasizing skin tumour (Graham and Helwig, 1959) and this disorder seems to represent a tendency to develop malignancies at various sites rather than a true paramalignant disorder. 
The relation between gastrointestinal haemorrhage and lung cancer is difficult to assess. In a necropsy study of 107 patients with lung cancer $21 \%$ showed an active gastric or duodenal ulcer (Ramah and Chomet, 1962). It must be remembered that $6 \%$ of working men aged between 45 and 64 years will complain of peptic ulcer symptoms (Doll and Jones, 1951). If the incidence of peptic ulcer is raised in lung cancer this may again, like diabetes, be related to the high serum cortisol levels found in lung cancer.

Some of the patients were under the care of Dr. S. G. Cotton and we are grateful for her permission to report them. We also wish to thank Dr. T. E. Deeley for helpful criticism of the manuscript.

\section{REFERENCES}

Anderson, G. (1973). Paramalignant Syndromes in Lung Cancer. Heinemann, London.

Azzopardi, J. G., Freeman, E., and Poole, G. (1970). Endocrine and metabolic disorders in bronchial carcinoma. British Medical Journal, 4, 528.

- and Whittaker, R. S. (1969). Bronchial carcinoma and hypercalcaemia. Journal of Clinical Pathology, 22, 718.

Barrett, N. R. (1967). Introduction. Some Aspects of Carcinoma of the Bronchus and Other Malignant Diseases of the Lung, p. 1. A symposium at King Edward VII Hospital, Midhurst, edited by D. Tear and J. Fenning.

Carey, V. C. I. (1966). The incidence of hypercalcemia in association with bronchogenic carcinoma. American Review of Respiratory Diseases, 93, 584.

College of General Practitioners (1962). A diabetic survey. Report of a working party. British Medical Journal, 1, 1497.

Croft, P. B. and Wilkinson, M. (1963). Carcinomatous neuromyopathy, its incidence in patients with carcinoma of the lung and carcinoma of the breast. Lancet, 1, 184. de Gennes, L., Bricaire, H., and Leprat, J. (1962). Paraneoplastic endocrine syndromes. Hypothyroidism and various endocrinopathies. Presse Médicale, 70, 2137.

Doll, R. and Jones, F. A. (1951). Occupational Factors in the Aetiology of Gastric and Duodenal Ulcers. Medical Research Council Special Report Series, No. 276. H.M.S.O., London.

Eliakim, M. and Pinchas, S. (1966). Degenerative verrucous endocardiosis. A clinicopathological study of 45 cases with reference to the protracted form of the disease. Israel Journal of the Medical Sciences, 2, 42.

Glicksman, A. S. and Rawson, R. W. (1956). Diabetes and altered carbohydrate metabolism in patients with cancer. Cancer, 9, 1127.

Graham, J. H. and Helwig, E. B. (1959). Bowen's 윽 disease and its relationship to systemic cancer. Archives of Dermatology, 80, 133.

Hatch, H. B., Segaloff, A., and Ochsner, A. (1965). Adrenocortical function in bronchogenic carcinoma. Study of 100 patients. Annals of Surgery, ฏ 161, 645 .

Pisapia, M. (1965). Sindromi endocrine associate a $\vec{\varphi}$ neoplasie: segnalazione di due casi di tumore or broncogeno con ipercorticismo e ipertiroidismo. Annals of Radiology, 31, 887.

Ramah, S. J. and Chomet, B. (1962). Bronchogenic carcinoma and peptic ulcer. Cancer, 15, 1117.

Rees, L. H. (1973). Hormone production by lung tumours. Tubercle, Supplement. 3, p. 49.

Semple, T. and McCluskie, R. A. (1955). Generalized $\overrightarrow{\vec{\partial}}$ hypertrophic osteoarthropathy in association with 3 bronchial carcinoma. A review based on 24 cases. British Medical Journal, 1, 754.

Soong, B. C. F. and Miller, S. P. (1970). Coagulation disorders in cancer. Cancer, $25,867$.

Yacoub, M. H. (1965). Relation between the histology of bronchial carcinoma and hypertrophic pulmonary osteoarthropathy. Thorax, 20, 537.

Requests for reprints to: Dr. Gerald Anderson, St. Woolos Hospital, Newport, Gwent. 